Łukasz JAKUBIAK

Jagiellonian University in Kraków

lukasz.jakubiak@uj.edu.pl

\title{
THE PARLIAMENTARY GENESIS OF THE FRENCH SEMI-PRESIDENTIALISM AGAINST THE BACKGROUND OF THE PROCESS OF PRESIDENTIALISATION OF THE FIFTH REPUBLIC
}

ABSTRACT The paper deals with the dynamics of the transformation of the semi-presidential system of government established under the constitution of the Fifth Republic of France. The author argues that the constitutional regime adopted in 1958 has been based on fundamental principles of a broadly parliamentary model (in particular, on the so-called dualistic parliamentarianism built on the balance between the executive and the legislative). Special attention was paid to the phenomenon of presidentialisation of the French version of the aforementioned model. This process is based on two main pillars - legal and political ones - and for several decades it has led to the gradual erosion of these elements of the system of government, which have been taken directly from parliamentarianism. This has resulted, first of all, in the emergence of the French semi-presidentialism, and then - in a significant weakening of its pro-parliamentary components. The author points out, however, that the strictly political dimension of presidentialisation of the system of government can be quite effectively, albeit temporarily, hampered by the occurrence of cohabitation. The latter phenomenon may be treated as a 'return to the letter of the constitution'. On the other hand, a remarkable reduction, with the use of legal instruments, in the probability of another cohabitation period is yet another aspect of the multifaceted process of presidentialisation.

Key words: the French Fifth Republic, a parliamentary system of government, semi-presidentialism, presidentialisation, majority effect, cohabitation 


\section{INTRODUCTION}

The French system of government is commonly referred to as a semi-presidential one, although the definition of semi-presidentialism is still under discussion. Particular problems are associated with determining the scope of presidential power. For some, the head of state should have considerable competencies. ${ }^{1}$ For others, it is only important that the president of the Republic is legitimised by universal suffrage and the cabinet is politically responsible before the legislative body. ${ }^{2}$ As a result of the latter concept, the constitutional powers of the head of state are of secondary importance. Anyway, in the framework of semi-presidentialism components of parliamentarianism and presidentialism may be distinguished, though the proportions between them are different, depending on a particular country. Focusing on the letter of the basic law of the French Fifth Republic (adopted in 1958), ${ }^{3}$ it could be argued that its regulations have been based on some typical mechanisms of a parliamentary model, which sets the basic constitutional structure of the French system of government (such elements as polical arbitration of the head of state or responsibility of the government before the parliament). However, although the genesis of the French semi-presidentialism seems to be firmly rooted in a parliamentary system, this aspect of the current French system of government has been clearly blurred. As a consequence, from today's point of view, which takes into account mainly the impact of political practice, such origins of the current constitution are not particularly prominent. It is also due to the fact that the process of presidentialisation began in the early years of the Fifth Republic, which did not allow for the consolidation of the whole pro-parliamentary paradigm. It can be argued, in view of the three interrelated phenomena, namely the Gaullist vision of presidency, the constitutional changes made since the first years of the Republic, as well as the influence of the political context (above all resulting from the stucture of party rivarly), that the apparent embedding of the French system of government in the parliamentary model does not currently play a big role.

This does not mean, however, that the aforementioned genesis of the French constitutional structure should not be subjected to a deeper analysis, concerning, among other things, the scope of the constitutionalisation of the semi-presidential system. The originality of the French formula of this model results from the mixing of components,

1 M. Duverger, "Le concept de régime semi-présidentiel", in idem (ed.), Les régimes semi-présidentiels, Paris 1986, p. 7. The strengthened position of the head of state is also contained in the definition of semipresidentialism presented by Giovanni Sartori. He insists on balance within the executive, but allows for a differentiated distribution of real power in political practice. G. Sartori, Comparative Constitutional Engineering. An Inquiry into Structures, Incentives and Outcomes, New York 1997, pp. 131-132.

2 R. Elgie, "What Is Semi-Presidentialism and Where Is It Found?", in idem, S. Moestrup (eds.) Semi-Presidentialism outside Europe. A Comparative Study, London-New York 2007, p. 6; idem, "The Politics of Semi-Presidentialism", in idem (ed.), Semi-Presidentialism in Europe, Oxford-New York 1999, p. 13.

3 La Constitution de la Ve République. Texte integral, Paris 2014. 
which have only a partial anchorage in the text of the constitution. This in particular affects the phenomenon of the flexibility of the French basic law (and thus of the entire system of government), which can be understood as the exceptional openness of this act to the influence of key political factors. ${ }^{4}$ It seems that without setting up a French version of semi-presidentialism on the basic rules of parliamentarianism, the influence of such properties would not be possible. Hence, the preservation of these elements of the constitutional structure that directly connects to parliamentary designs can be regarded as an effective obstacle to the transition - on the constitutional plane - from the existing semi-presidential model to a pure presidential one. For this reason, even if there are some legal changes concerning the system of government, they seems to be merely complementary and do not permanently exclude the rules based on a parliamentary model. Consequently, special attention should be devoted to the preliminary view that it is the parliamentary component of the current system of government, although severely marginalised, that still indirectly defines the identity of the most important constitutional mechanisms. It can be assumed that presidentialisation which is visible in political practice goes beyond the text of the constitution, so there is no strong normative basis for this process. In any case, the parliamentary roots of the Fifth Republic protect the contemporary French semi-presidential structure from the consequences of its unlimited presidentialisation which could possibly take place in the process of exercising power. On the other hand, even if the pro-presidential reading of the current basic law cannot lead to a departure from the existing semi-presidential construction based on parliamentary components, it is undoubtedly the preferred interpretation of the institutions established almost 60 years ago. It could be argued that the possibility of the opposite evolution, that is parliamentarisation of the system of government has been evidently limited.

\section{THE DOCTRINAL BACKGROUND OF THE RENEWED FRENCH PARLIAMENTARIANISM}

The constitutional ideas of the founding fathers of the Fifth Republic were reflected in the comprehensive description of this act, which Michel Debré, the minister of justice and one of the authors of the new basic law, presented before the Council of the State (Conseil d'Etat) on 27 August 1958..$^{5}$ It was clear from his description of political institutions regulated in the new constitution that their creators stood firmly on the ground of a parliamentary system of government, but striving for its fundamental reform. The purpose of the Gaullist camp was therefore to maintain parliamentarianism, but in a heavily modified form, thus rejecting its disclosed deficiencies. Particularly strong criticism relating to the system of government existing before 1958 was

For more on this topic, see: J. Szymanek, "Zagadnienie 'otwartości' konstytucji V Republiki Francuskiej”, Państwo i Prawo, no. 10 (2010), pp. 47-59.

5 “Discours de M. Michel Debré devant le Conseil d'Etat le 27 août 1958”, in D. Maus (ed.), Les grands textes de la pratique constitutionelle de la Ve République, Paris 1998, p. 3. 
triggered, among other things, by the functioning of republican political institutions after the introduction of the so-called Constitution Grévy. This was a kind of a strictly political interpretation of the most important constitutional mechanisms, which meant the imposition of a new systemic paradigm. ${ }^{6}$ It is worth noting that a common denominator of the Third (1875-1940) and Fourth Republics (1946-1958) was the application of a monistic version of the parliamentary model (régime parlementaire moniste). ${ }^{7}$ One of the essential features of this form of parliamentarianism is the apparent imbalance within the executive branch. Such a differentiation of the position of the government and the head of state results from the phenomenon of far-reaching political neutralisation of the latter body. This is the effect of the departure from the earlier version of a parliamentary model, that is, of dualistic parliamentarianism (régime parlementaire dualiste), where ministers are politically linked to the parliament but still remain dependent on the head of state whose position is relatively strong. In light of these assumptions, the head of state is capable of influencing the activities of ministers who bear political responsibility not only before the parliament but also before the head of state as a crucial organ existing within the two-headed executive power. Besides, in the relations with the legislature, the head of state has the right to its dissolution, which is not restricted by the existence of different constraints, so it can be relatively freely used. This means the realisation of the concept based on the relatively balanced executive, which was fully revisited after the transition to the aforementioned monistic formula through the adoption of the constitution of $1875 .^{8}$

6 The term 'constitution Grévy' has been introduced by a French constitutionalist Marcel Prélot. It was a specific interpretation of the constitution of the Third Republic. Such a specific reading was imposed in 1879 by the then president Jules Grévy. He declared that he would not fight against the national will (volonté nationale) expressed by the constitutional organs. In his conviction, this was a basis of a parliamentary system included in the 1875 constitution. See: J.J. Chevalier, Histoire des institutions et des régimes politiques de la France de 1789 à nos jours, Paris 1981, pp. 310-311. In practice, the constitution Grévy would assume a permanent resignation of the head of state from applying the dissolution of parliament. This in turn meant the destabilisation of the system, because it lacked the necessary balance. This was due to the fact that the parliament could easily overthrow governments. All this meant the de facto introduction of absolute parliamentarianism which had nothing in common with the postulate of constitutional and political stabilisation of a parliamentary regime. Such a concept also affected the functioning of the Fourth Republic in the years 1946-1958. D. Turpin, Le régime parlementaire, Paris 1997, pp. 54-62.

A sharp critic of the institutional mechanisms built into a parliamentary system in its extremely monistic version was Michel Debré, one of the most significant creators of the constitutional order existing after the fall of the Fourth Republic in 1958. For more on this topic, see: S. Aromatario, La pensée politique et constitutionnelle de Michel Debré, Paris 2006, pp. 66-73.

8 In the political practice of the Third and Fourth Republics, the most important consequence of the latter was the apparent instability of governments which were particularly susceptible to criticism from the parliament. The then cabinets were not able to consolidate its political position in relations with the legislature. The cause lay in the fact that in the formula of monistic parliamentarianism of the Third and Fourth Republics there were no mechanisms to stabilise the government in a situation of unstable parliamentary support. Moreover, the neutralised head of state, which lacked sufficient tools to effectively influence the process of governance, was unable to function as a political arbitrator stabilising the entire political system. 
The reform proposals that the founding fathers of the Fifth Republic, such as Charles de Gaulle and Michel Debré, formulated in the 1940s and 1950s were a response to the defects of the monistic version of a parliamentary system. The expected changes were supposed to enhance both segments of the executive: the president of the Republic and the government. It cannot, however, lead to the conclusion that there was no difference between the framers of the new basic law in terms of how to strengthen it. Although they pointed to the need to improve the position of the executive power as such, accents were distributed unevenly. For de Gaulle, the reinforcement of presidential power was of particular importance. The head of state was to regain a wider field of action, but this did not mean that the duality principle of executive power would have been liquidated. The president, however, had to function over various political divisions, which would have put him, in some sense, outside the strictly structured executive power. Such an assumption was consistent with the role of the head of state as a political arbitrator, and therefore with the concept of presidential power that is, generally speaking, typical of any form of parliamentarianism. What deserves to be emphasized is that in the case of the Fifth Republic such arbitration had to be exceptionally strong. Hence, the head of state was to have some specific constitutional powers (applied without ministerial countersignature) that could influence the functioning of the entire institutional structure. One of the tools of such a strong arbitration consists, first and foremost, in the right to dissolve parliament. ${ }^{9}$ De Gaulle also attached importance to the institution of referendum. In his view, it was the head of state that was supposed to be the body that could manage the conduct of such a nationwide vote. Both instruments constituted the core of the Gaullist concept of presidency based on the departure from the model of the head of state implemented under the constitutions of the Third and Fourth Republics. It should be highlighted that a common denominator for both aforementioned institutions was to ensure a balance within the system of government, which was intended to limit the position of the parliament (particularly strong before 1958). Its dissolution directly strengthened the executive power, and the referendum (which allowed a bill to be passed without a parliamentary track) broke with the legislative exclusivity of the chambers (a nation has become the legislator without the participation of parliamentarians). In de Gaulle's concept of a new constitutional order, repeatedly presented during the Fourth Republic, the expected institutional structure was undoubtedly embedded in a parliamentary model.

In turn, Michel Debré, minister of justice in de Gaulle's cabinet appointed in June 1958 and chief editor of the new constitution, put special emphasis on the strengthening of the government towards the legislature. His concept of the parliamentary system was presented in the 1940s, long before the adoption of the constitution of the Fifth Republic. The presidential power itself and the question of its expected reform was not

9 It may be considered that the return to the idea of dissolving the legislative body by the head of state was to break with the concept launched in the Third Republic when the constitution Grévy was in force. As Maus noted, the dissolution of parliament was then seen as a crime against the existing democratic order. D. Maus, Études sur la Constitution de la Ve République. La mise en place, la pratique, Paris 1990, p. 126. 
particularly stressed by him. Debré was clearly on the ground of the reform, not liquidation, of parliamentarianism. His main objective was to stabilise the government in relations with the parliament as well as to limit the position of the latter body. Thus, the planned changes were to result in the immediate departure from ineffective monistic variant of parliamentarianism. Among the solutions that Debré promoted, there were postulates such as the limitation of the lawmaking competencies of the parliament and the strengthening of the government's powers in this area. In addition, possible modifications were to be made regarding the powers of the parliament to control government activities. In this regard, too strong position of the legislative power meant a weakened durability of the cabinets, which - as political practice of the Third Republic shows - fell down on average every a few months, most often without a good reason. Despite attempts at systemic reforms, the same situation was repeated after the Second World War, during the Fourth Republic. This led to the failure of the first concepts aimed at the rationalisation of the relationship between the executive and legislative power. ${ }^{10}$ Like de Gaulle, Debré also drew attention to the merits of the dissolution of parliament, which was supposed to ensure effective resolution of disputes between the legislature and the government. All this showed unequivocally that the purpose of such reforms was to rationalise parliamentarianism and thus ensure its sustainability and efficiency.

The views on constitutional issues formulated by the founding fathers of the new basic law prior to 1958, were directly reflected in its final text. It must be remembered, however, that the constitution of the Fifth Republic was prepared under the direction of the government headed by de Gaulle, but its authors also had to take into account the rigors imposed by the parliament of the Fourth Republic. Hence, the constitutional law of 3 June $1958^{11}$ was adopted. The act governed the most important principles of the future basic law. These rules were laid down when de Gaulle's cabinet was appointed. Its main task was to prepare the necessary constitutional changes. First of all, it needs to be stressed that, according to the aforementioned provisions, the new constitution was to maintain a broadly understood parliamentary system of government. Although such a direction of constitutional works resulted directly from the very concept of the founding fathers, but the need to preserve the fundamental structure of this model was also regulated in a formal manner. Therefore, one of the legal requirements was to ensure the separation of various authorities and to maintain the principle of responsibility of the cabinet before the legislature, which is at the heart of each parliamentary regime. As mentioned above, the reception of these principles, however, was fully in line with the constitutional ideas of the founders of the Fifth Republic. It is legitimate to believe that the fundamental purpose of the analysed systemic changes was a profound modification of parliamentarianism, which, however, would not have led to its replacement

10 O. Gohin, Droit constitutionnel, Paris 2013, pp. 542-545.

11 Loi constitutionnelle du 3 juin 1958 portant dérogation transitoire aux dispositions de l'article 90 de la Constitution et prévoyant un référendum, Journal Officiel de la République Française, 4 June 1958, p. 5326. French legal acts are available at $<$ https://www.legifrance.gouv.fr $>$. 
with a completely different constitutional model. After all, it is possible to implement different concepts of relations between the authorities within the entire framework of a parliamentary system. The ensuring of its effectiveness does not necessarily lead to a complete rejection of fundamental mechanisms on which parliamentarianism is built.

A fundamental alternative to a parliamentary system, that is, a presidential model was then explicitly questioned. Debré confirmed this point of view during the aforementioned speech before the Council of the State. At the same time, he defined precise conditions for a properly constructed parliamentary system. They were based on his earlier presented concept of a profound reform of parliamentarianism. According to Debré, there was a need for important reforms in order to regulate, in a restrictive way, parliamentary sessions, to determine the scope of parliamentary legislative activity, to reform profoundly the procedure of adopting laws, as well as to introduce mechanisms to ensure balance of the authorities and their proper functioning. ${ }^{12}$ Changes in these areas were undoubtedly the core of rationalisation activities. All of them were aiming, to a greater or lesser degree, to rebuild relations between the institutions influencing the design of the whole system of government. Their common component was the need to limit the strong status of the legislative body resulting from political and constitutional ideas adopted before 1958 (the constitution Grévy as a manifestation of extremely monistic version of parliamentarianism) in order to restore a fundamental sistemic balance. What is more, the excessive role of political parties was to be weakened. ${ }^{13}$ Hence, from the point of view of the structure of the newly-created parliamentary system, the most important issue consisted in the reconstruction of relations between the government and the legislature. The far-reaching strengthening of the former took place in areas such as the legislative procedure and the parliamentary responsibility of the cabinet. This was intended to stabilise this body in the absence of sufficient support from the legislature, in line with the concept of rationalised parliamentarianism. ${ }^{14}$ It must be stressed that all the changes remained within the limits of a broadly understood parliamentary system, although they significantly modified its existing monistic formula.

\section{THE PRO-PARLIAMENTARY COMPONENTS OF THE 1958 CONSTITUTION AND THEIR SUBSEQUENT MODIFICATIONS}

The outlined concept of the reformed parliamentary system was reflected in the original text of the constitution, which was passed in the referendum on 4 September 1958. First of all, the constitutional model of presidency has been based on the concept of political arbitration in its strongest formula. The main role of the president, referred

12 “Discours de M. Michel Debré...”, p. 3.

13 F. Dreyfus, “The Control of Governments”, in P.A. Hall, J. Hayward, H. Machin (eds.), Developments in French Politics, New York 1990, p. 133.

14 A. Knapp, V. Wright, The Government and Politics of France, London-New York 2001, p. 135. 
to in article 5, is to ensure - through arbitration - the continuity of public authorities. For example, the head of state can effectively, through almost unlimited right to dissolve the legislature, interfere in relations between the latter body and the government. On the other hand, in accordance with article 20, the task of defining and conducting the state policy rests with the government responsible only before the parliament. This meant that while the president is to run the work of the Council of Ministers - the only legally regulated form of government meetings - there is no constitutional basis for his activism in determining the state policy. Such a division of powers within the executive is characteristic of the model in which the head of state is more or less neutralised in terms of their impact on the political process. Such a president usually plays a role of representative of the state, deprived of real power. In the light of the wording of the constitution, the key role of the government seems to be, therefore, beyond doubt. However, the original design of presidency was affected by the lack of universal presidential election. At the beginning of the Fifth Republic the head of state was chosen by a special electoral college which consisted of about 80,000 members. They were parliamentarians and representatives of local assemblies. ${ }^{15}$

It should also be stressed that the authors of the constitution did not assume the political responsibility of the government before the head of state. In 1958, only the parliamentary one was introduced (before the first chamber - the National Assembly). Thus, the head of state does not have the power to dismiss the government at his own initiative. A prior request by the prime minister is formally required. The lack of formalisation of political responsibility of the government to the head of state is another manifestation of the parliamentary nature of the French constitution. This proves that, contrary to appearances, the framers of the current constitution did not seek, at least at the beginning, to create a strict hierarchy within the executive branch, which is typical of a pure presidential system. It must be borne in mind that the head of state was - as de Gaulle expected - to operate over different authorities (mainly the legislative and executive power), but it was primarily attributable to the model of the president as an arbitrator, which shapes the relationship between other bodies in order to ensure balance within the whole political system. All this leads to the opinion that, although the presidency can be considered a factor binding the whole constitutional architecture (according to Debré, the head of state under the Fifth Republic should be treated as the keystone - clef de voute - of the political regime ${ }^{16}$ ), the basic structural axis of the system of government has been based on two bodies: the government and the parliament. This is due to the fact that the principle of political responsibility referred only to those political components. Consequently, there was no reason to deny the view that the constitution in its original form adopted in 1958 contained another embodiment of the rules of a parliamentary model. Although, as a result of the

15 This procedure was applied only once - in 1958, when Charles de Gaulle was elected president. Despite the lack of strong electoral legitimacy, de Gaulle's political influence was based on historical merits during the Second World War and on often conducted referendums in which the public supported his policies.

16 “Discours de M. Michel Debré...”, p. 5. 
aforementioned reforms, the legislature was weakened and could no longer politically dominate other organs within the system of government, institutional balance, which was the main purpose of the fathers of the constitution, did not cause the rejection of the structure of parliamentarianism. On the contrary, the basic rules of a parliamentary model were better protected by the basic law itself. This resulted from the fact that the constitution was supposed to prevent its possible deformations in political practice.

However, the original text of the constitution, which could be regarded as favourable to the parliamentary system, was substantially modified in subsequent years. Thus, the impact of at least some constitutional (and legislative) changes cannot be ignored. The most important institutional reform in the history of the Fifth Republic concerned undoubtedly the mode of electing the president. The corresponding constitutional amendment was adopted in $1962 .{ }^{17}$ This modification was crucial from the point of view of the constitutional design of the adopted system of government. The presidency, which does not have direct social legitimacy, constitutes a component of a significant number of contemporary parliamentary systems. In such an institutional context the head of state is, above all, a political arbitrator who is above daily party rivalry and interferes in the process of governance only from time to time. ${ }^{18}$ For this reason, the introduction of universal presidential elections has gone beyond the change of the electoral procedure itself. The modification of 1962 has led to the reinterpretation of the constitutional model of presidency. The head of state has been given a strong social mandate, corresponding with the Gaullist vision of exercising power. What deserves to be emphasized is that, as a result of this constitutional change, the French system of government has lost its strong ties with the conventional parliamentary model. The introduction of universal presidential elections, combined with the 1958 regulations, was an important step towards the French semi-presidential formula. ${ }^{19}$ At the same time, this was a remarkable factor contributing to the phenomenon of the future presidentialisation (understood as a far-reaching strengthening of the head of state, which has no direct constitutional basis) of the system of government adopted in the Fifth Republic. ${ }^{20}$

Discussing the constitutional factors that have influenced the consolidation of the paradigm of presidentialism in political practice, attention should be paid to the

17 The universal and direct voting took place for the first time three years later, after the first de Gaulle's seven-year term.

18 This favours its political neutralisation, which is characteristic, to a greater or lesser degree, for any particular form of a parliamentary system.

19 Hence, Duverger expresses the view that such a system was introduced in France through the reform of 1962. M. Duverger, La monarchie républicaine ou comment les démocraties se donnent des rois, Paris 1974, p. 187.

20 This is, however, only one of possibile dimensions of the process of presidentialisation that has become clearly visible in political systems of the contenporary states. For more on this topic, see: Th. Poguntke, Ph. Webb, "The Presidentialization of Politics in Democratic Societies: A Framework for Analysis", in iidem (eds.), The Presidentialization of Politics. A Comparative Study of Modern Democracies, Oxford-New York 2005, pp. 1-25. 
shortening of the term of the head of state to five years (quinquennat). ${ }^{21}$ From the perspective of the constitutional construction of the French presidency, this change was crucial. As a result, the term of office of the head of state and the term of office of the National Assembly were to be the same. This did not mean, however, that both terms were supposed to start simultaneously. A regulation presuming that these two kinds of elections would be held on the same day was not considered at the time. It should be pointed out that this was not the intent of the authors of this reform. The shortening of the presidential term should rather be seen through the prism of the existing political configuration. The decision concerning the aforementioned constitutional amendment was made under the conditions of the third cohabitation (1997-2002). It is worth noting that the phenomenon of politically divided executive power was extremely frequent in the 1980s and 1990s. Among the causes of such a situation, one can mention significant changes in the party system contributing to the periodic alternation of power. Due to defferentiated terms of office of the president and of the first chamber, the situation in which the majorities in the latter body were in opposition to the head of state was much more likely. ${ }^{22}$ All this caused the shortening of the presidential term of office to be perceived as a change that was to be reflected directly in the exercise of power. The main aim of such amendments could be reduced to the avoidance of another cohabitation period, commonly considered to have many more disadvantages than advantages. The reform itself did not guarantee this, but clearly reduced the risk.

As a result, the possibility of parallel running of the terms of office of the president and of the first chamber has been created. However, the election of the head of state for five years does not yet determine which body will be elected first. It depends, in general, on the electoral calendar. Based on the assumption that the presidential and parliamentary elections are to be held in close time intervals, the order of both elections is crucial to the political system. The shortening of the president's term has shown that the so-called majority effect (fait majoritaire), in which the whole executive power is politically coherent, has become the preferred political configuration. However, a relative fixation of such a variant had to be preceded by further normative changes, taking place at the statutory level and consisting in 'reordering' the electoral calendar. The problem was connected with the fact that, due to the dissolution of the National

21 Loi constitutionelle $\mathrm{n}^{\circ} 2000-964$ du 2 octobre 2000 relative à la durée du mandat du Président de la République, Journal Officiel de la République Française, 3 October 2000, p. 15582. The decision was made in a referendum held on 24 September 2000. In comparison with almost all referendums under the Fifth Republic the turnout was exceptionally low, amounting to sligtly more than $30 \%$. Over $70 \%$ of voters chose a five-year term. F. Hamon, Le Référendum. Étude comparative, Paris 2012, pp. 109-110.

22 This happened in particular five years after presidential elections. In 1981 and 1988 Mitterrand dissolved the National Assembly, which meant that the next parliamentary elections were to take place two years before the end of the presidential term of office. It was a special occasion for the opposition to the ruling camp. As a result, the two first cohabitation periods began in 1986 and 1993. More broadly on the beginning of the configuration of politically heterogeneous executive branch see: B. Chantebout, Brève histoire politique et institutionnelle de la Ve République, Paris 2004, pp. 144-151, 172-173. 
Assembly by Jacques Chirac in 1997, the 2002 parliamentary elections were scheduled to take place before the presidential elections that also had to be held in the same year. Such a configuration of both types of popular elections would in practice mean the primacy of those to the National Assembly. While presidential and parliamentary ones involve two different legislative and executive bodies, which are not hierarchically subordinated, the term 'primacy of elections' should in this case be understood as the ability to designate, autonomously, a new political configuration. It seems that conducting the presidential elections on the second place would have most likely led to the situation in which voters would have had to adjust their choices to the outcome of an earlier creation of a majority in the first chamber. This, in turn, would have undermined the political significance not only of presidential elections but also of the French presidency as such. In other words, the relationship between the so-called presidential majority (majorité présidentielle) and the parliamentary majority would have been considerably modified. The latter would have become a natural reference point, which would have had to be considered not only under possible cohabitation but also under majority effect. It can be assumed that in such a situation the phenomenon of presidentialisation of the French system of government would have been largely inhibited. This was the reason for the restoration, by statutory measures, ${ }^{23}$ of the earlier electoral configuration (the priority of the presidential elections as the most important political electoral event of the French). ${ }^{24}$ Taking into consideration the possible impact of the normative changes adopted in the years 2000-2001, it cannot be surprising that the reodering of the electoral celendar was then widely regarded as a natural consequence of the introduction of the five-year presidential term. ${ }^{25}$

The new constitutional and legislative regulations introduced in 2000 and 2001 resulted in the fact that the 'manual' correction of the time of the parliamentary elections in order to maintain majority effect was no longer needed. Before the reform under discussion, a particular role in such adjustments can be attributed to the dissolution of the parliament on the basis of article 12 of the constitution, which since the 1980s has ceased to serve as a presidential arbitration instrument at all, becoming instead a basic tool of correcting existing political configurations in the interest of the head of state. This situation occurred for the first time in 1981, when the candidate of the Socialist Party - François Mitterrand - won the presidential elections at the time, after more than twenty years of center-right domination. Under such conditions, resignation from the dissolution of the first chamber must have meant the beginning of cohabitation.

23 The Organic Act of 15 May 2001, composed of only two articles, provided that the term of the National Assembly expires on the third Wednesday of June, the fifth year after the election (article 1). This regulation was to apply to the first chamber which was elected in 1997 (article 2). Loi organique n²001-419 du 15 mai 2001 modifiant la date d'expiration des pouvoirs de l'Assemblée nationale, Journal Officiel de la République Française, 16 May 2001, p. 7776.

24 For more on this topic, see: Ł. Jakubiak, "Francja", in J. Szymanek (ed.), Niedemokratyczne wymiary demokratycznych wyborów, Warszawa 2016, pp. 424-432.

25 C. Bedock, Reforming Democracy. Institutional Engineering in Western Europe, Oxford-New York 2017, pp. 189-191. 
The application of article 12 of the basic law was therefore seen as a way to prevent a political coexistence of two opposing camps, which is always - regardless of specific circumstances of each such a period - much less favorable to the head of state than the majority effect. It is worth mentioning that the same situation repeated in 1988, after Mitterrand's re-election. The last dissolution of parliament (in 1997) was slightly different, but also in this case the purpose of the head of state was to avoid cohabitation. President Jacques Chirac decided to take such a step only two years after the 1995 presidential elections, and not directly after them. However, such a strategy of the head of state cannot be surprising. In 1995, there was no need to apply article 12 because the center-right supporting Chirac was dominant in the National Assembly. The situation changed due to the forthcoming parliamentary elections scheduled for 1998. Taking into account the need to maintain majority effect, the dissolution of parliament by Chirac proved to be completely ineffective, leading to the start of a five-year cohabitation period (it went on until the 2002 presidential and parliamentary elections). ${ }^{26}$ What should be particularly emphasized is that the application of article 12 has not been repeated since then. Thus, over the past 20 years this constitutional provision has been a dead letter. Consequently, this has led to further weakening of these systemic components, which can traditionally be linked to a parliamentary model. It should be borne in mind, however, that in the case of France such a weakening occurred earlier, when article 12 became a tool for creating the most expected political configurations instead of an instrument for resolving real conflicts between the legislative and the executive (eg. after passing a motion of censure and lack of opportunity to choose a new cabinet supported by a parliamentary majority).

It should be pointed out that the declining importance, due to the legal changes in the years 2000-2001, of the aforementioned 'manual' corrections has been confirmed by the results of both types of elections held in 2002, 2007, 2012 and 2017. In each case, the presidential elections preceded the parliamentary ones. What is more, the latter were always held a few weeks after the first. As a result, the political configuration of the $\mathrm{Na}$ tional Assembly has always been shaped by the overwhelming influence of the newly-established presidency. It is worth noting that in the first three elections the beneficiaries of such an electoral calendar were two main formations that dominated the French party system in previous decades, namely the neogaullist centre-right (2002 and 2007) and the left-wing camp led by the socialists (2012). However, a different situation occurred in 2017, when none of the two dominant parties succeeded in the presidential elections. Neither François Fillon from the centre-right Republicans (Les Républicains, LR) nor

26 The dissolution of parliament in order to obtain the propresidential majority in the first chamber always generates some danger of unfavorable outcome for the presidential camp. This is a form of indirect political responsibility of the head of state, who in the event of failure of his own presidential party must - according to an often expressed concept - either surrender to a new majority or resign (se soumettre ou se demettre). C. Debbasch et al., La Ve République, Paris 1988, p. 303. In practice, Chirac had to limit significantly his polical impact as a result of the 1997 electoral outcome. It is worth noting that in other cases $(1962,1968,1981,1988)$, the dissolution of parliament always brought the result expected by the head of state (although in 1988 the socialists and their allies obtained only a relative majority). 
Benoit Hamon, who was a candidate of the Socialist Party (Parti Socialiste, PS), entered the second round. ${ }^{27}$ Although the election was won by Emmanuel Macron, who did not have a strong party support (he was backed by his own political movement founded a year before the elections), the problem of a completely unstable and unpredictible majority in the National Assembly has not emerged. Thus, it can be said that the double election of 2017 has proved to be a true test of the legal mechanism intended to preserve majority effect. Most importantly, this solution worked even when the candidate of the so-called third party managed to win the presidency. It can be said that the impact of the presidential elections was so strong that it led to a very remarkable redevelopment of the arena of party rivalry consisting in simultaneous marginalisation of the party ruling in the years 2012-2017 and the largest opposition formation in that period.

\section{THE PRO-PRESIDENTIAL DISTORTION OF THE FRENCH PARLIAMENTARIANISM IN POLITICAL PRACTICE}

It should be pointed out that the normative changes of the years 2000-2001 would not have been so strong without the simultaneous impact of the political context. The most important factor was the emergence after the 1962 election of a stable majority supporting the cabinet and the head of state. It marked the beginning of majority effect which, as noted above, assumed the political homogeneity of both segments of the executive and at least of the majority in the first chamber. ${ }^{28}$ What is more, as a result of popular presidential elections (the first of them took place in 1965), the head of state could play the role of a founder and unifier of its own, more or less multi-tier, political camp. In the case of the second round of parliamentary elections (conducted with the use of a majority system), the most important thing was whether the candidate belongs to the political allies of the president or joins the opposition camp. ${ }^{29}$ Thus, parliamentary elections have been very closely linked to presidential ones (even if their temporal convergence was not needed and did not occur).

The consolidation of the politically unified executive structure was an essential factor in rebuilding the French system of government and resigning from the implementation

27 "Résultats de l'élection présidentielle 2017", Ministère de l'intérieur, at <https://www.interieur. gouv.fr/Elections/Les-resultats/Presidentielles/elecresult_presidentielle-2017/(path)/presidentielle-2017/FE.html>, 9 August 2017.

28 The government does not bear political responsibility before the Senate, which results in the support of this chamber not being required for its functioning. There is no doubt, however, that the existence of stable pro-governmental majorities in both chambers is an optimal situation for each French cabinet. Otherwise, the prime minister must more often use the tools of rationalised parliamentarianism (eg. the procedure of the last word - dernier mot - of the National Assembly in legislative proceedings). Such a situation occured for the first time 1981, after a left-wing shift of power in the National Assembly and a simultanous maintainance of the centre-right Senate. More on the French secondo chamber in the period of of frequent changes in parliamentary political configurations see: P. Smith, The Senate of the Fifth Republic, Basingstoke-New York 2009, pp. 57-92.

29 B. Chantebout, La Constitution française. Propos pour un débat, Paris 1992, pp. 56-58. 
of a parliamentary model regulated in the constitutional provisions. Changes of this kind could be noticed against the background of political practice when Michel Debré was the prime minister (1959-1962). As the author of the concept of a renewed parliamentary system, he recognized the need to follow the letter of this act. However, the interpretation of the role of the most important political institutions in the spirit of a deeply rebuilt parliamentarianism resulted then from a combination of several different factors, including lack of universal presidential elections. Debré emphasized, among other things, the role of cabinet councils (conseils de cabinet) ${ }^{30}$ - the informal meetings of the prime minister and ministers without the participation of the president who, under article 9 of the 1958 constitution presides over meetings of the Council of Ministers (Conseil des ministres). Thanks to this, the head of state could be shifted, at least to a certain extent, from the day-to-day work of the government. ${ }^{31}$ Therefore, the president could be more like a political arbitrator over political divisions. However, this does not change the fact that according to the concept of the then created reserved domain (domaine réservé), the president was to have a direct influence on foreign and defense policies (and also on the status of Algeria, which gained independence only in 1962), while the internal policy was to be run by the government more autonomously. ${ }^{32}$ This meant the division of powers within the executive branch, which deviated from the content of article 20 of the constitution. On its basis, the government defines and conducts state policy without any limitation on its scope.

Still, the concept of the reserved domain was relatively favourable to the government. Later, after the introduction of the presidential election by universal suffrage and the change of a party configuration in the National Assembly, it was assumed that the head of state could directly influence policy in every aspect. The cabinet was supposed to be the organ intended to implement the presidential policy. De Gaulle presented this point of view at a press conference in 1964, when the notion of the reserved domain, understood not only as a departure from the letter of the constitution to the benefit of the head of state, but also as a limitation of the president's influence on specific issues (all other areas of state policy), was evidently challenged. As a result, de Gaulle went

30 M. Duverger, Le système politique français, Paris 1990, pp. 319-320.

31 Later, the practice of meetings of the cabinet councils was, however, abandoned and it revived only during the period of cohabitation, when the government tried to hold the meeting without the head of state from another political camp. In this way, the practice of the two former Republics was partially restored. The meetings of the cabinet councils were then much more frequent, because the Council of Ministers acted in a more formal rather than substantive way. This body was mainly used to approve decisions that had been taken earlier. Due to the strengthening of the presidency, the establishment of the Fifth Republic has, with some exceptions, led to the resignation of this practice. B. Chantebout, Brève histoire..., pp. 39-41.

32 The idea of the reserved domain was presented at the beginning of the Fifth Republic by Jacques Chaban-Delmas, one of the politicians belonging to the Gaullist camp. However, this concept was later questioned. Its application at the threshold of the Fifth Republic was rather tactical, accentuating the special role of the president in relation to Algeria. The reserved domain was, however, reemerged in the conditions of cohabitation when it was necessary to redefine the actual position of the head of state and institutional relations within the executive branch. D. Chagnollaud, J.-L. Quermonne, $L e$ gouvernement de la France sous la Ve République, Paris 1996, pp. 259-261. 
one step further, pointing to the need for a real hierarchy within the executive branch. It can be inferred from his concept that the president was to occupy a dominant position within the executive branch, and that the role of the government, including the prime minister, was to be rather an auxiliary to the head of state. To justify this approach to the institutions set up at the turn of the 1950s and 1960s, de Gaulle strongly emphasized the importance of popular presidential elections, stating that the president was 'a man of the nation, chosen by it to respond to its destiny' (l'homme de la nation, mis en place par elle-même pour répondre de son destin). ${ }^{33}$ Such a concept of relationship within the executive has undermined, to some extent, the idea of presidency that was active but politically neutral at the same time (it should be noted, however, that political neutrality of the presidency does not necessarily mean its political neutralisation and far-reaching marginalisation). Hence, in de Gaulle's concept, there was not much room for government's political independence from the head of state. It seems that such specific relationships within the executive branch contributed to the further erosion of the parliamentary regime maintained (but decisively renewed) at the beginning of the Fifth Republic. The rejection of monistic parliamentarianism developed during the two former Republics was, of course, the result of the 1958 constitution itself, but later political ideas went even further, leading to a severe disturbance of relative equilibrium within the executive branch, which was shaped by the constitutional provisions. It should be borne in mind that in the light of the Gaullist concept of power, the president and the government were to function primarily according to the model of the hierarchy, which assumed the primacy of the head of state, and the evident subordination of the prime minister and other ministers. ${ }^{34}$

The imposition by the Gaullist camp of a specific reading of the constitution of the Fifth Republic has been directly reflected in relations between the president and the government. From the point of view of the output structure of the adopted parliamentary system of government and its subsequent transformations under the 1958 basic law, the most characteristic is the emergence, informally, of the principle of political responsibility of the cabinet before the head of state. This happened in the mid-60s when the prime minister was Georges Pompidou, Debré's successor. The head of government at that time challenged one of the pillars of each parliamentary system, namely the duty of verifying parliamentary support immediately after parliamentary elections. ${ }^{35}$ Instead, support of the head of state was regarded as a prerequisite for the functioning of the government. This systemic change involved simultaneous occurrence of two interrelated processes: the greater the dependence of the government on the president,

33 "Déclaration du général de Gaulle sur le rôle du Président de la République. Conférence de presse du 31 janvier 1964", in D. Maus (ed.), Les grands textes..., p. 43.

34 It's hard to disagree with Pierre Bourdon who notes that the practice of exercising power within the system of the Fifth Republic was based on the assumption that the head of state itself interprets its own competencies. Two constitutional elements serve as the basis for this. First, legitimacy in universal elections, and second, the article 5, in which the president guarantees the observance of the basic law. P. Bourdon, Le quinquennat, cinq ans après, Paris 2008, p. 55.

35 J. Chapsal, La vie politique sous la Ve République, Paris 1984, p. 316. 
the less the dependence of the former on the parliament. Hence, the redefinition of the relationship in the triangle of the president-government-parliament can be considered as the most important political fact of the Fifth Republic. The practice of majority effect giving the president much more than the letter of the constitution remained in line with the Gaullist concept, which assumes the supremacy of the head of state within the existing institutional structure. The prime minister resigns as expected by the head of state and, although it is not justified in the basic law, after presidential elections. The latter is to demonstrate the freedom of the newly elected president to appoint a cabinet that would meet the expectations of the head of state (but provided that there exists a pro-presidential majority). All this reveals some highly pro-presidenial components of the French semi-presidential structure seen through the prism of political practice. ${ }^{36}$

However, two basic reservations are necessary. Firstly, in practice, the relationship between the president and the government has varied according to a political context. Of course, the key change was the occurrence of cohabitation, which consisted in breaking the political subordination of the cabinet to the head of state. The double responsibility of the government was then reduced to a single one, i.e., responsibility exclusively to the parliament (only such was regulated in the 1958 constitution). For this reason, the opinion that the return to the letter of the constitution (un retour a la lettre de la constitution ${ }^{37}$ was taking place in the course of cohabitation was at least to some extent justified. However, it needs to be stressed that the deterioration of relations between the president and the prime minister took place not only in the conditions of cohabitation. Some examples might be the functioning of the executive while the chiefs of government were Jacques Chaban-Delmas (1969-1972, under the presidency of Georges Pompidou) and Jacques Chirac (1974-1976, under the presidency of Valéry Giscard d'Estaing). ${ }^{38}$ Secondly, strong ties between the government and the president under the conditions of majority effect do not mean that the prime ministers did not

36 In this respekt, there is a similarity to the American presidentialism where the political influence of the presidential elections extends to the personal composition of the entire executive branch. O. Duhamel, Le quinquennat, Paris 2000, p. 32. The important difference, however, is that under the French conditions, the choice made in presidential elections must be confirmed by parliamentary ones (unless the presidential option prevails in the first chamber). Anyway, the prime ministers' resignation immediately after the newly-elected head of state takes office proves the dependence of the prime minister on the president, which goes beyond the norms of the constitution.

37 Such a view is based primarily on 'the restoration' of articles 20 and 21 of the 1958 constitution, according to which it is the government (responsible before the parliament), not the president, to determine and conduct a state policy. Asd noted earlier, under such conditions, the head of state ceases to be an actual legislator (through the parliament and legal acts issued by the executive) and becomes a political arbitrator in the traditional sense of the word. A.-X. Fournier, La dynamique du pouvoir sous la Ve République. Cohabitation et avenir des institutions, Québec 2008. On the other hand, there is also the opinion that the aforementioned return to the letter of the constitution after the emergence of cohabitation was not complete. The latter view is typical of the proponents of treating the Fifth Republic as a parliamentary system (at the very least as a slightly modified one). From this point of view, many actions of the head of state during majority effect meant the violation of the basic law. M.-A. Cohendet, La cohabitation. Leçons d'une expérience, Paris 1993, pp. 294-295.

D. Maus, Études sur la Constitution..., p. 176. 
expect the vote of confidence of the National Assembly at all. Even before the occurrence of the first period of cohabitation in 1986, they decided to take this step with varying frequency, and some also sought support from the Senate. ${ }^{39}$ It clearly shows that the verification of parliamentary support, although not considered mandatory, took place in practice. In fact, parliamentary responsibility was thus not completely neutralised, although the confidence of parliamentarians was mainly treated as alleged. This presumption could have always been overturned by members of the National Assembly themselves (by passing a motion of censure to the government). The importance of parliamentary support, however, increased significantly after the commencement of cohabitation. As Massot pointed out, the head of state could not then oppose the application of article 49 of the basic law. ${ }^{40}$ As demonstrated in practice, in such conditions the prime minister also verified the confidence of a pro-governmental majority in the second chamber, if possible (only during the two first periods of cohabitation started in 1986 and 1993). ${ }^{41}$ Hence, the need for a constant consideration of parliamentary configurations proves that despite the pro-presidential interpretation of the constitution (even if it goes beyond its letter), the parliamentary genesis of the basic law was still clearly visible.

\section{THE IMPACT OF THE PARTY RIVARLY ON PRESIDENTIALISATION OF THE FRENCH SYSTEM OF GOVERNMENT}

The presidentialisation of the political system taking place in political practice has gone beyond the specific interpretation of the basic law itself as well as beyond the normative changes that were supposed to support such an approach to the contitutional text. This phenomenon has also affected some other components of the political system than the

39 Resignation from applying for a vote of confidence in the National Assembly has never referred to a particular political option. This strategy was chosen by politicians such as Maurice Couve de Murville (the centre-right) and Michel Rocard (the left). In some cases, however, this was directly related to another manifestation of presidentialisation of the political system, namely the appointment, after presidential elections, of the prime minister and the government from the camp of the new head of state, even though there was still a parliamentary majority created by its political opponents. This refers to the situation in which the president simultaneously decided to dissolve parliament. This meant that such cabinets functioned for only about a month and were based solely on the legitimacy of the head of state. After parliamentary elections won by the presidential option, a new government with a very similar composition had to be appointed. J.-C. Colliard, "Article 49, 50 et 51", in F. Luchaire, G. Conac, X. Prétot (eds.), La Constitution de la République française. Analyses et commentaires, Paris 2009, p. 1249-1250, 1267-1268.

J. Massot, Chef de l'Etat et chef du gouvernement. Dyarchie et hiérarchie, Paris 1993, p. 124.

41 J.-C. Colliard, “Article 49...”, pp. 1267-1268. Between 1997 and 2002 the Senate did not belong to the left-wing camp. It was an ally of the president Chirac, who was opposed to the socialist prime minister Lionel Jospin. For this reason, the latter could not count on support of most of the senators. In this respect, the third cohabitation differed significantly from the previous two. A. Delcamp, "L'affirmation du Sénat", in B. Mathieu (ed.), Cinquantième anniversaire de la Constitution française, 1958-2008, Paris 2008, p. 284. 
institutions of the legislative and executive powers, which were regulated by the constitutional provisions. Such elements of the complex structure of the state are political parties that under the conditions of the Fifth Republic have begun to act in accordance with the logic of a highly presidentialised semi-presidential system. The central institution of this model is the presidency, which means that political parties treat it as a reference both at the stage of the fight for the presidential mandate and during the term of the elected candidate. The phenomenon of presidentialisation of the French political parties can be seen through the prism of strategies they adopt in the arena of political rivalry. This is very much tied to the struggle to win or maintain the presidency. Thus, it can be concluded that the parties play a significant role as auxiliary institutions, becoming tools for candidates in presidential elections or for the head of state rather than fully autonomous political bodies. A good example is the change of the name of Jacques Chirac's formation in connection with the 2002 presidential and parliamentary elections. Since 1976, the party had been called the Rally for the Republic (Rassemblement pour la République). To emphasize its role as the necessary parliamentary backbone of the head of state, the name used in the 2002 legislative elections was the Union for the Presidential Majority (Union pour la majorité présidentielle, UMP). The focus of smaller center-right parties around Chirac's candidature also served to unite the entire presidential camp. ${ }^{42}$ Before the parliamentary elections held in 2002, it was a clear signal to voters that Chirac had expected the creation of a new parliamentary majority to ensure the implementation of the presidential electoral programme. Once this target was met, the name of the neogaullist party was changed, after several months, to the Union for a Popular Movement (Union pour un mouvement populaire, UMP). ${ }^{43}$ All this shows that the renaming of the formation in connection with the election campaign was tightly subordinated to the strategy of building a broad presidential camp in parliament, thus avoiding another cohabitation period.

The fight for the presidency may also serve as a benchmark for the emergence of a completely new political formation. This is illustrated by the rivalry for the presidency in 2017 and subsequent parliamentary elections. Emmanuel Macron's victory has been a key factor in the significant rebuilding of the political scene following the parliamentary elections that took place a few weeks later. During François Hollande's presidency, Macron was a member of the Socialist Party and the minister of economy, industry and digital affairs in the government headed by Manuel Valls, but did not decide to take part in the primaries of the aforementioned formation. Instead, he founded, in April 2016, his own political movement, Onwards! (En Marche!). ${ }^{44}$ In the 2017 parliamentary elections, the formation took part as The Republic Onwards!

42 A. Hall, Historia francuskiej prawicy 1981-2007, Kraków 2009, p. 429-430. More on the creation of the UMP as a centre-right presidential party uniting diverse political currents see: A. Knapp, "From the Gaullist Movement to the President's Party", in J. Evans (ed.), The French Party System, Manchester-New York 2003, pp. 130-136.

43 É. Agrikoliansky, Les partis politiques en France, Paris 2008, pp. 106-107.

44 V. Gas, "Macron est-il en marche pour 2017?", RFI, 7 April 2016, at <http://www.rfi.fr/ france/20160407-macron-est-il-marche-2017-mouvement-marche>, 10 August 2017. 
(La République En Marche!) and won an absolute majority of seats (the group of The Republic Onwards! is composed of 310 out of 577 members of the first chamber ${ }^{45}$ ), decisively defeating traditional formations that had dominated the French political scene before the double elections: the neogullists and the socialists. It must be pointed out that the most important result of these elections was a radical transformation of the structure of the contemporary French party system. Before the elections, it seemed that the position of the two mainstream parties had been well established. This rebuilding of the political landscape would not, however, be possible without the influence of the presidential elections. This can be considered as a factor triggering a remarkable change in the attitude of voters. Regardless of previous political affiliations, they have decided to provide the new head of state with a favourable parliamentary configuration. As a result, voting for candidates motivated by the need to maintain majority effect shows that parliamentary elections are not autonomous but closely linked to the outcome of the presidential ones. Thus, a completely new presidential party was created. What is more, thanks to the fact that the real patron of The Republic Onwards! is the incumbent president, the party won - in the first nationwide election in which it participated - the overwhelming majority of mandates in the $\mathrm{Na}$ tional Assembly, guaranteeing the further existence of majority effect. What deserves special attention is that the influence of the outcome of the 2017 presidential elections on the behaviour of the electorate in the parliamentary ones held a few weeks later was so strong that it led to immediate marginalisation, at least at the parliamentary level, of parties with a deeply-rooted position in the structure of the party system. It must be noted that in well-established democracies, such a sudden reconstruction of the arena of party rivalry is not a frequent occurrence.

Taking into account the practice of exercising power, it should be stated that the above-mentioned role of political parties as a component incorporated into presidential strategies is very significant. This is due to the fact that this gives rise to political control over the parliament (at least over the first chamber, which is elected in popular elections almost immediately after presidential ones). Under such conditions, the head of state becomes the real leader of a parliamentary majority, which in turn exerts an influence on maintaining hierarchical relations within the executive branch. As a consequence, there is no high risk of the situation in which the president is indeed a participant of a ruling camp, but its leader is not the head of state, but the prime minister. ${ }^{46}$ All this leads to the conclusion that the existence of a specific presidential party contributes to the preservation of the primacy of the head of state in the institutional structure of the state. The president then obtains all necessary political tools (including his own presidential party), which do not allow the limitation of its actual position. It means that the organ is not exclusively an arbitrator in relations between

45 "Modifications à la composition des groupes", Assemblée nationale, at <http://www2.assemblee-nationale.fr/qui/modifications-a-la-composition-des-groupes>, 10 August 2017.

46 Such a formula was theoretically considered by Duverger, who, however, did not notice its occurrence in political practice of the first four decades of the Fifth Republic. M. Duverger, Le systeme..., pp. 529-531. In this respect, the situation has not changed since the 1990s. 
other authorities and thus remains far from the model of presidency in a pure parliamentary system. However, it proves that the strength of the presidential power is heavily dependent on the political configuration in the National Assembly. It can be said that the formula composed of the president and of the government which is politically subordinated to the head of state, is only possible when a strong presidential party has a majority of seats in the first chamber and thus is able to protect its cabinet against successful motions of censure. ${ }^{47}$

\section{FINAL REMARKS}

One of the key aspects of the systemic changes introduced in France at the end of the 1950s was the reconstruction of the relationship between the legislature and the executive, which was supposed to affect the whole system of government. From the point of view of the concept of the state, the reform of the parliamentary model was particularly significant. The basic aim was therefore a profound renewal of parliamentarianism applied before 1958. The purpose of the Gaullists' modifications was to rebuild the system by introducing mechanisms to stabilise its daily functioning. These changes followed two paths simultaneously - through the redefinition of the presidential power (establishment of a strong arbitration presidency) and by strengthening the government in relations with the parliament (for example, constant government control of the course of legislative proceedings). This has led to the emergence of the French semi-presidential model, where there are two strong centres of the executive power. It was therefore a rejection of a monistic parliamentary formula in which the status of the executive is relatively weak, and the parliament is seen as a body with a central position. Hence, the new constitutional paradigm was based on the limitation of political significance of the national representation centred in the parliament. This has resulted in a far-reaching reformulation of the axiology underlying the entire constitutional order created after the fall of the Fourth Republic.

The most important aspect of the French variant of rationalisation was, however, the strengthening of the head of state, which meant a far-reaching reinforcement of the executive as such to the parliament. This is due to the fact that the constitutional model of presidency under the Fifth Republic was the anchor point for the deep political changes that have taken place in practice. The configuration of majority effect has considerably strengthened the semi-presidentialism of the Fifth Republic, exposing the principle of dual responsibility of the cabinet - not just before the parliament but also

47 More on the presidentialisation of the French political formations and on the notion of a presidential party under the Fifth Republic see: Ł. Jakubiak, "Zjawisko prezydencjalizacji partii politycznych we francuskim systemie partyjnym”, in M. Wincławska (ed.), Partie polityczne w początkach XXI wieku. Problemy rozwoju, organizacji ifunkcjonowania, Toruń 2013, pp. 449-469; T. Godlewski, "Wpływ systemu politycznego na partie polityczne we Francji na przykładzie partii prezydenckiej”, in T. Koziełło, P. Maj, W. Paruch (eds.), Adaptacja, reforma, stabilizacja. Przestrzeń publiczna we wspótczesnych systemach politycznych, Rzeszów 2010, pp. 339-350. 
before the president. Although cohabitation has revealed the parliamentary roots of the existing system of government, this configuration lasted only a total of only nine years, and thus it was an exception to the rule. Importantly, the responsibility of ministers before the president was then strongly rejected. The head of state had to cooperate with ministers from the opposition political camp. According to the logic of a pure parliamentary system, the political backing for the government was then centred only in the legislature. All this proves that the French semi-presidential system is also able to function in a more parliamentarised form.

The normative changes that were adopted after the end of the third period of cohabitation, however, have gone in the direction of preserving the paradigm of actual presidentialism. Such a conclusion stems from the introduction of the five-year presidential term and the change of the electoral calendar. The practice of the last fifteen years shows that it has allowed for an effective reduction in the risk of cohabitation, although, as Cohendet noted, the resignation from the highly presidentialised institutional design and the occurrence of the fourth period of politically divided executive power cannot be completely excluded. ${ }^{48}$ It is now legitimate to believe that the significance of the systemic components that have been based on the structure of a parliamentary model is much smaller than fifteen years ago when the phenomenon of cohabitation was a part of the political practice. What is more, the most important French political institutions have been inscribed, to a certain extent, into the logic of American presidentialism, where a rigid electoral calendar corresponds with the lack of a possibility to dissolve the parliament and pass a motion of censure. In the case of France, both measures exist, but they have become merely formal. The first and last case of passing a motion of censure was in 1962, and the National Assembly has not been dissolved for over twenty years. In France, this situation is only the result of political practice. The effective use of these two mechanisms is not, however, ruled out (attempts to pass a motion of censure are taken very often, but because of the political structure of the first chamber, they do not produce any remarkable results).

What deserves special attention is that such effects have been achieved without introducing constitutional changes eliminating regulations based on the logic of each parliamentary system of government. As a consequence, presidentialism is part of contemporary practice of governance, while parliamentarianism is perceptible only at the level of legal provisions. Thus, the latter is basically only a potential phenomenon which can become part of the French constitutional practice only if the mechanisms that secure presidentialisation of the regime prove to be unreliable. What is more, under the Fifth Republic, the practice consisting in the realisation of a parliamentary model has emerged only in the variant of cohabitation. The second possibility, that is, the configuration in which the head of state belongs to the parliamentary majority camp but is not its leader, has never occurred. Anyway, cohabitation has been largely neutralised

48 This can be seen as an important factor in institutional relations within the French political regime regarded through the prism of the so-called system of variable determinants (le systeme de variables déterminantes) discussed by Cohendet. M.-A. Cohendet, "Le système de variables déterminantes", in Constitutions et pouvoirs. Mélanges en l'honneur de Jean Gicquel, Paris 2008, p. 132. 
by some normative changes. In turn, the passive presidency within the framework of majority effect has been blocked by the very logic of the functioning of political institutions at the threshold of the Fifth Republic. This second variant of 'the return to the letter of the constitution' could not develop, at any stage, in the functioning of the system established at the end of the 1950s. As a result, the government headed by the prime minister has never become a real beneficiary of the political uniformity of the executive branch under the 1958 constitution. It all leads to the conlusion that apart from the phenomenon of cohabitation which existed before 2002, various blockades protecting from possible long-lasting parliamentarisation of the regime ${ }^{49}$ that have been imposed in political practice, seems to be very effective.

\section{BIBLIOGRAPHY}

Agrikoliansky É., Les partis politiques en France, Paris 2008.

Aromatario S., La pensée politique et constitutionnelle de Michel Debré, Paris 2006.

Bedock C., Reforming Democracy. Institutional Engineering in Western Europe, Oxford-New York 2017.

Bourdon P., Le quinquennat, cinq ans après, Paris 2008.

Chagnollaud D., Quermonne J.-L., Le gouvernement de la France sous la Ve République, Paris 1996.

Chantebout B., Brève histoire politique et institutionnelle de la Ve République, Paris 2004.

Chantebout B., La Constitution française. Propos pour un débat, Paris 1992.

Chapsal J., La vie politique sous la Ve République, Paris 1984.

Chevalier J.J., Histoire des institutions et des régimes politiques de la France de 1789 à nos jours, Paris 1981.

Cohendet M.-A., La cohabitation. Leçons d'une expérience, Paris 1993.

Cohendet M.-A., "Le système de variables déterminantes", in Constitutions et pouvoirs. Mélanges en l'honneur de Jean Gicquel, Paris 2008.

Colliard J.-C., "Article 49, 50 et 51", in F. Luchaire, G. Conac, X. Prétot (eds.), La Constitution de la République française. Analyses et commentaires, Paris 2009.

La Constitution de la Ve République. Texte integral, Paris 2014.

Debbasch C. et al., La Ve République, Paris 1988.

"Déclaration du général de Gaulle sur le rôle du Président de la République. Conférence de presse du 31 janvier 1964", in D. Maus (ed.), Les grands textes de la pratique constitutionelle de la Ve République, Paris 1998.

49 It should be noted that some important constitutional reforms introduced in 2008 by the constitutional act concerning the modernisation of the institutions of the Fifth Republic (Loi constitutionnelle $\mathrm{n}^{\circ}$ 2008-724 du 23 juillet 2008 de modernisation des institutions de la Ve République, Journal Officiel de la République Française, 24 July 2008, p. 11890) have not changed anything in the structure of the French semi-presidentialism. The relative reinforcement of the legislative Power that was the main object of the aforementioned changes cannot be treated as a factor influencing the existing constitutional designs relating to the applied system of government. 
Delcamp A., "L'affirmation du Sénat", in B. Mathieu (ed.), Cinquantième anniversaire de la Constitution française, 1958-2008, Paris 2008.

“Discours de M. Michel Debré devant le Conseil d'Etat le 27 août 1958”, in D. Maus (ed.), Les grands textes de la pratique constitutionelle de la Ve République, Paris 1998.

Dreyfus F., “The Control of Governments”, in P.A. Hall, J. Hayward, H. Machin (eds.), Developments in French Politics, New York 1990.

Duhamel O., Le quinquennat, Paris 2000.

Duverger M., "Le concept de régime semi-présidentiel", in idem (ed.), Les régimes semi-présidentiels, Paris 1986.

Duverger M., La monarchie républicaine ou comment les démocraties se donnent des rois, Paris 1974.

Duverger M., Le système politique français, Paris 1990.

Elgie R., "The Politics of Semi-Presidentialism”, in idem (ed.), Semi-Presidentialism in Europe, Oxford-New York 1999.

Elgie R., "What Is Semi-Presidentialism and Where Is It Found?", in idem, S. Moestrup, Semi-Presidentialism outside Europe. A Comparative Study, London-New York 2007.

Fournier A.-X., La dynamique du pouvoir sous la Ve République. Cohabitation et avenir des institutions, Québec 2008.

Gas V., "Macron est-il en marche pour 2017?", RFI, 7 April 2016, at <http://www.rfi.fr/ france/20160407-macron-est-il-marche-2017-mouvement-marche>.

Godlewski T., "Wpływ systemu politycznego na partie polityczne we Francji na przykładzie partii prezydenckiej”, in T. Koziełło, P. Maj, W. Paruch (eds.), Adaptacja, reforma, stabilizacja. Przestrzeń publiczna we wspótczesnych systemach politycznych, Rzeszów 2010.

Gohin O., Droit constitutionnel, Paris 2013.

Hall A., Historia francuskiej prawicy 1981-2007, Kraków 2009.

Hamon F., Le Référendum. Étude comparative, Paris 2012.

Jakubiak Ł., "Francja”, in J. Szymanek (ed.), Niedemokratyczne wymiary demokratycznych wyborów, Warszawa 2016.

Jakubiak Ł., "Zjawisko prezydencjalizacji partii politycznych we francuskim systemie partyjnym”, in M. Wincławska (ed.), Partie polityczne w poczatkach XXI wieku. Problemy rozwoju, organizacji i funkcjonowania, Torun 2013.

Knapp A., "From the Gaullist Movement to the President's Party", in J. Evans (ed.), The French Party System, Manchester-New York 2003.

Knapp A., Wright V., The Government and Politics of France, London-New York 2001.

Loi constitutionnelle du 3 juin 1958 portant dérogation transitoire aux dispositions de l'article 90 de la Constitution et prévoyant un référendum, Journal Officiel de la République Française, 4 June 1958.

Loi constitutionnelle $\mathrm{n}^{\circ} 2000-964$ du 2 octobre 2000 relative à la durée du mandat du Président de la République, Journal Officiel de la République Française, 3 October 2000.

Loi constitutionnelle $\mathrm{n}^{\circ} 2008-724$ du 23 juillet 2008 de modernisation des institutions de la V $V^{e}$ République, Journal Officiel de la République Française, 24 July 2008.

Loi organique $\mathrm{n}^{\circ}$ 2001-419 du 15 mai 2001 modifiant la date d'expiration des pouvoirs de l'Assemblée nationale, Journal Officiel de la République Française, 16 May 2001.

Massot J., Chef de l'Etat et chef du gouvernement. Dyarchie et hiérarchie, Paris 1993. 
Maus D., Études sur la Constitution de la Ve République. La mise en place, la pratique, Paris 1990.

"Modifications à la composition des groupes", Assemblée nationale, at <http://www2. assemblee-nationale.fr/qui/modifications-a-la-composition-des-groupes $>$.

Poguntke Th., Webb Ph., "The Presidentialization of Politics in Democratic Societies: A Framework for Analysis", in iidem (eds.), The Presidentialization of Politics. A Comparative Study of Modern Democracies, Oxford-New York 2005.

"Résultats de l'élection présidentielle 2017", Ministère de l'intérieur, at < https://www.interieur. gouv.fr/Elections/Les-resultats/Presidentielles/elecresult__presidentielle-2017/(path)/ presidentielle-20 17/FE.html>.

Sartori G., Comparative Constitutional Engineering. An Inquiry into Structures, Incentives and Outcomes, New York 1997.

Smith P., The Senate of the Fifth Republic, Basingstoke-New York 2009.

Szymanek J., “Zagadnienie 'otwartości' konstytucji V Republiki Francuskiej”, Państwo i Prawo, no. 10 (2010).

Turpin D., Le régime parlementaire, Paris 1997.

Eukasz JAKUBIAK, PhD is a political scientist and jurist; an assistant professor in the Chair of Constitutionalism and Systems of Government in the Institute of Political Science and International Relations at the Jagiellonian University in Cracow. His scientific interests mainly concern political systems of the French Fifth Republic and of francophone African states. 